\title{
SOLVENT EXTRACTION OF Co, Ni AND Mn FROM NCM SULFATE LEACHING SOLUTION OF Li(NCM)O SECONDARY BATTERY SCRAPS
}

As a part of the study on recycling $\mathrm{Li}(\mathrm{NCM}) \mathrm{O}_{2}$ lithium-ion battery scraps, solvent extraction experiments were performed using different extraction agents such as PC88A, Cyanex272 and D2EHPA to separate Co, $\mathrm{Ni}$ and $\mathrm{Mn}$ from the leaching solution. When the ratio of $\mathrm{Mn}$ to $\mathrm{Ni}$ was about 0.4 in the leaching solution, the separation factor for Co and Mn was found to be less than 10 so that the separation of $\mathrm{Co}$ and $\mathrm{Ni}$ was insufficient. When solvent extraction was done using the solution with the lower $\mathrm{Mn} / \mathrm{Ni}$ ratio of 0.05 where Mn was removed by potassium permanganate and chlorine dioxide, more than $99 \%$ of Mn could be extracted through five courses of extraction using 30vol\% D2EHPA while the extraction rates of Co and Ni were around 17\% and 11\%, respectively. In the case that Mn was removed from the solution, the extraction rate of Co was higher than $99 \%$ whereas less than 7\% Ni was extracted using Cyanex272 suggesting that Co and Ni elements were effectively separated.

Keywords: Waste recycling, NCM-system lithium ion battery, Reduction, Leaching

\section{Introduction}

As electronics industries have been developed, lithium secondary batteries are widely applied to electronic equipment such as a mobile phone and a laptop computer that need high performance and efficient energy [1-4]. The $\mathrm{LiCoO}_{2}$ (LCO) system as a cathode material has been largely employed to small electronic goods. However, they are not proper for medium-tobig sized devices due to the high cost of cobalt and the possibility of explosion. Under the circumstance, the $\mathrm{Li}\left(\mathrm{Ni}_{\mathrm{x}} \mathrm{Co}_{\mathrm{y}} \mathrm{Mn}_{\mathrm{z}}\right) \mathrm{O}_{2}$ (NCM) system has been interested for hybrid electric vehicles as a high power cathode material.

Many studies have been done to recover valuable materials from lithium-ion battery scraps [5-13]. In 1998, Zhang et al. examined the effects of leaching agent concentration, temperature, leaching time and solid-to-liquid ratio on recovery rate of $\mathrm{Li}$ and Co by using hydrochloric acid leaching and also investigated the solvent extraction to recover $\mathrm{Co}$ and $\mathrm{Li}$ from spent lithium-ion batteries [5]. In the 2000s, the studies on recycling of spent LCO batteries became vitalized. Contestable et al. of Italy studied the recovery of Co from spent lithium-ion batteries to reuse it as a cathode material [6]. Lee and Kim studied the reductive leaching behavior of $\mathrm{LiCoO}_{2}$ at sulfuric acid solution and established the leaching condition [7]. Castillo et al. studied leaching effects of dilute acid that came from spent lithium-ion batteries and the selective precipitation in the form of hydroxide [8]. In 2005, Nan et al. recovered $\mathrm{Cu}$ and Co using Acorga-5640 and
Cyanex272 by treating active materials of spent lithium secondary batteries with alkali before leaching them with sulfuric acid and precipitating Co in the form of oxalate [9]. In 2011, Kim et al. performed a study to produce precursor of $\mathrm{Ni}, \mathrm{Co}$ and $\mathrm{Mn}$ cathode materials through physical/chemical treatment of spent lithium-ion battery pack for EVs and also to produce lithium carbonate using co-precipitation solution [12].

This investigation is the one of the series study of authors. Previously, valuable metals like Co, Ni and Mn were recovered without removing $\mathrm{Li}$ by sodium carbonate. In the study, it was found that Na worked as impurity so the multiple washing should be required. Hence, the authors published papers on recovering Li first from NCM system cathode scraps by reductive treatment and sulfuric acid leaching of NCM powder [13,14]. Given the studies above, this study examined extraction characteristics of $\mathrm{Co}, \mathrm{Ni}$ and $\mathrm{Mn}$ to separate and recover them from NCM sulfuric acid solution from which Li was removed through a reductive treatment and also to produce the optimal separation condition for each element.

\section{Experimental}

The sample used in this experiment was NCM system cathode scraps generated from the process of manufacturing lithiumion batteries by a Korean company. Lithium was removed by hydrogen or carbon reductive treatment and sulfur acid leaching

\footnotetext{
* DEPARTMENT OF INTERDISCIPLINARY ECO SCIENCE, SUNGSHIN UNIVERSITY, SEOUL, KOREA

** ADVANCED MATERIALS \& PROCESSING CENTER, INSTITUTE FOR ADVANCED ENGINEERING (IAE), YONGIN-SI, KOREA

*** DEPARTMENT OF MATERIALS SYSTEM ENG., PUKYONG UNIVERSITY, BUSAN, KOREA

**** KOREA INSTITUTE OF CERAMIC ENGINEERING AND TECHNOLOGY, ICHEON, KOREA

\# Corresponding author: mdsimul@iae.re.kr
} 
solution was used $[13,14]$. The samples were leached by aqua regia and their chemical compositions were analyzed by ICP (Inductively Coupled Plasma, GBC Integra XL).

As for agents used for solvent extraction, D2EHPA (di2-ethylhexyl phosphoric acid, Hanyang Lab. Sci. Service) was used to remove Mn while PC88A (2-ethylhexyl phosphonic acid mono-2-ethylhexyl ester, Hanyang Lab. Sci. Service) and Cyanex272 (di-2,4,4,-trimethylpentyl phosphinic, Hanyang Lab. Sci. Service) was used to separate $\mathrm{Co}$ and $\mathrm{Ni}$, respectively. Meanwhile, Escaid100 (Hanyang Lab. Sci. Service) was also used as a diluent that removed aroma from kerosene.

The experiment mixed $\mathrm{pH}$-adjusted leaching solution and organics that contained leaching agent, reacted them for some time, did phase separation after 60 minutes, filtered the aqueous solution, measured concentration of metal ions and estimated leaching rate of each metal. It also removed Mn from NCM sulfur acid leaching solution with the oxidants, potassium permanganate and chlorine dioxide to perform solvent extraction.

\section{Results and discussion}

The distribution coefficients, the separation coefficients and the separation rates of $\mathrm{Co}, \mathrm{Ni}$ and $\mathrm{Mn}$ from NCM solution using PC88A and Cyanex272 are listed in Table 1. In general, Cyanex272 showed higher separation rates for Co and Mn comparing to PC88A. With the $\mathrm{Mn} / \mathrm{Ni}$ ratio of 0.4 , the separation coefficient was found to be 10 or below even though PC88A and Cyanex272, known effective to separate $\mathrm{Co}$ and $\mathrm{Ni}$, were used. This suggested that the separation was not efficient for these conditions. Ni should be separated in a solution but organic

TABLE 1

Results of solvent extraction on NCM sulfate solution (initial pH: 5.5)

\begin{tabular}{|c|c|c|c|c|c|c|}
\hline & \begin{tabular}{|c|} 
O/A \\
ratio**
\end{tabular} & $\begin{array}{l}\text { Eq. } \\
\text { pH }\end{array}$ & $\begin{array}{l}\text { Ele- } \\
\text { ment }\end{array}$ & $D$ & $\beta$ & $E(\%)$ \\
\hline \multirow{3}{*}{$\begin{array}{l}\text { PC88A } \\
-10 \%\end{array}$} & \multirow{3}{*}{1} & \multirow{3}{*}{7.0} & Co & 1.11 & $\mathrm{D}_{\mathrm{Co}} / \mathrm{D}_{\mathrm{Ni}}=1.20$ & 52.6 \\
\hline & & & $\mathrm{Ni}$ & 0.93 & & 48.1 \\
\hline & & & $\mathrm{Mn}$ & 2.39 & $\mathrm{D}_{\mathrm{Mn}} / \mathrm{D}_{\mathrm{Ni}}=2.58$ & 70.5 \\
\hline \multirow{3}{*}{$\begin{array}{l}\text { PC88A } \\
-15 \%\end{array}$} & \multirow{3}{*}{1} & \multirow{3}{*}{5.2} & Co & 1.36 & $\mathrm{D}_{\mathrm{Co}} / \mathrm{D}_{\mathrm{Ni}}=1.49$ & 57.6 \\
\hline & & & $\mathrm{Ni}$ & 0.91 & & 47.7 \\
\hline & & & Mn & 3.94 & $\mathrm{D}_{\mathrm{Mn}} / \mathrm{D}_{\mathrm{Ni}}=4.31$ & 79.8 \\
\hline \multirow{3}{*}{$\begin{array}{l}\text { PC88A } \\
-20 \%\end{array}$} & \multirow{3}{*}{1} & \multirow{3}{*}{4.2} & Co & 1.41 & $\mathrm{D}_{\mathrm{Co}} / \mathrm{D}_{\mathrm{Ni}}=1.62$ & 58.4 \\
\hline & & & $\mathrm{Ni}$ & 0.87 & & 46.4 \\
\hline & & & Mn & 3.94 & $\mathrm{D}_{\mathrm{Mn}} / \mathrm{D}_{\mathrm{Ni}}=4.54$ & 79.7 \\
\hline \multirow{3}{*}{$\begin{array}{c}\text { Cyanex272 } \\
-10 \%\end{array}$} & \multirow{3}{*}{2} & \multirow{3}{*}{5.5} & Co & 1.60 & $\mathrm{D}_{\mathrm{Co}} / \mathrm{D}_{\mathrm{Ni}}=1.82$ & 76.2 \\
\hline & & & $\mathrm{Ni}$ & 0.88 & & 63.8 \\
\hline & & & $\mathrm{Mn}$ & 3.54 & $\mathrm{D}_{\mathrm{Mn}} / \mathrm{D}_{\mathrm{Ni}}=4.02$ & 87.6 \\
\hline \multirow{3}{*}{$\begin{array}{c}\text { Cyanex272 } \\
-15 \%\end{array}$} & \multirow{3}{*}{2} & \multirow{3}{*}{4.4} & Co & 1.32 & $\mathrm{D}_{\mathrm{Co}} / \mathrm{D}_{\mathrm{Ni}}=1.92$ & 72.6 \\
\hline & & & $\mathrm{Ni}$ & 0.69 & & 57.9 \\
\hline & & & Mn & 3.01 & $\mathrm{D}_{\mathrm{Mn}} / \mathrm{D}_{\mathrm{Ni}}=4.37$ & 85.8 \\
\hline \multirow{3}{*}{$\begin{array}{c}\text { Cyanex272 } \\
-20 \%\end{array}$} & \multirow{3}{*}{2} & \multirow{3}{*}{4.1} & Co & 1.27 & $\mathrm{D}_{\mathrm{Co}} / \mathrm{D}_{\mathrm{Ni}}=2.00$ & 71.7 \\
\hline & & & $\mathrm{Ni}$ & 0.63 & & 55.9 \\
\hline & & & $\mathrm{Mn}$ & 3.06 & $\mathrm{D}_{\mathrm{Mn}} / \mathrm{D}_{\mathrm{Ni}}=4.82$ & 86.0 \\
\hline
\end{tabular}

*: Oil/Aqua phase ratio synthesis went beyond $40 \%$ because Mn content was too high to separate Co and Ni. Consequently, it was thought that NCM solution containing high $\mathrm{Mn}$ content was inefficient to separate other elements by solvent extraction so the reduction of $\mathrm{Mn}$ concentration in a leaching solution is recommended.

To reduce the high content of Mn in NCM sulfur acid leaching solution, potassium permanganate $\left(\mathrm{KMnO}_{4}\right)$ as an oxidant was added to the solution. Liquefied potassium permanganate was slowly added to distilled water and was kept for an hour to enhance the precipitation reaction. Table 2 shows the Mn removal efficiency by potassium permanganate as well as the impact on $\mathrm{Co}$ and $\mathrm{Ni}$ co-leaching rates. When the experiments were at various $\mathrm{pH}$ conditions, $\mathrm{Mn}$ removal efficiencies were higher than 95\% but $\mathrm{Co}$ and $\mathrm{Ni}$ were co-precipitated by Mn precipitation, leaving 56 to $64 \%$ of $\mathrm{Co}$ and 61 to $73 \%$ of Ni in the NCM solution. This is not a desirable outcome because it meant loss of expensive $\mathrm{Co}$ and $\mathrm{Ni}$ and recovery of them was inefficient. Therefore, another way was needed to remove Mn so the volume of potassium permanganate was adjusted in the study to minimize precipitation of Co and Ni but failed to avoid their loss.

TABLE 2

Results of Mn removal from NCM solution using $\mathrm{KMnO}_{4}$

\begin{tabular}{|c|c|c|c|c|}
\hline Conditions & $\begin{array}{c}\text { Co } \\
\text { leaching } \\
\text { rate }\end{array}$ & $\begin{array}{c}\mathrm{Ni} \\
\text { leaching } \\
\text { rate }\end{array}$ & $\begin{array}{c}\text { Mn } \\
\text { leaching } \\
\text { rate }\end{array}$ & $\mathbf{M n} / \mathbf{N i}$ \\
\hline $\begin{array}{c}\mathrm{pH}=2 \\
\mathrm{Mn} / \mathrm{KMnO}_{4}=1.5\end{array}$ & $63.5 \%$ & $72.6 \%$ & $3.5 \%$ & 2.0 \\
\hline $\begin{array}{c}\mathrm{pH}=3 \\
\mathrm{Mn} / \mathrm{KMnO}_{4}=1.5\end{array}$ & $58.9 \%$ & $64.2 \%$ & $3.0 \%$ & 1.9 \\
\hline $\begin{array}{c}\mathrm{pH}=4 \\
\mathrm{Mn} / \mathrm{KMnO}_{4}=1.5\end{array}$ & $55.6 \%$ & $61.2 \%$ & $2.1 \%$ & 1.4 \\
\hline $\begin{array}{c}\mathrm{pH}=2, \\
\mathrm{Mn} / \mathrm{KMnO}_{4}=4.5\end{array}$ & $61.6 \%$ & $58.5 \%$ & $20.6 \%$ & 13.4 \\
\hline $\begin{array}{c}\mathrm{pH}=2, \\
\mathrm{Mn} / \mathrm{KMnO}_{4}=4.0\end{array}$ & $63.2 \%$ & $60.2 \%$ & $22.5 \%$ & 14.2 \\
\hline $\begin{array}{c}\mathrm{pH}=2, \\
\mathrm{Mn} / \mathrm{KMnO}_{4}=3.5\end{array}$ & $70.0 \%$ & $70.8 \%$ & $17.2 \%$ & 9.2 \\
\hline $\begin{array}{c}\mathrm{pH}=2, \\
\mathrm{Mn} / \mathrm{KMnO}_{4}=3.0\end{array}$ & $63.8 \%$ & $65.5 \%$ & $8.8 \%$ & 5.1 \\
\hline $\begin{array}{c}\mathrm{pH}=2, \\
\mathrm{Mn} / \mathrm{KMnO}_{4}=2.0\end{array}$ & $50.4 \%$ & $61.5 \%$ & $2.5 \%$ & 2.6 \\
\hline $\begin{array}{c}\mathrm{pH}=4, \\
\mathrm{Mn} / \mathrm{KMnO}_{4}=2.5\end{array}$ & $62.4 \%$ & $73.8 \%$ & $15.2 \%$ & 8.4 \\
\hline $\begin{array}{c}\mathrm{pH}=4, \\
\mathrm{Mn} / \mathrm{KMnO}_{4}=2.0\end{array}$ & $61.9 \%$ & $75.1 \%$ & $2.9 \%$ & 1.6 \\
\hline
\end{tabular}

Though Mn was effectively removed by potassium permanganate, it was not totally satisfactory in the view of loss of Co and Ni. Therefore, in the study, the different oxidant of chlorine dioxide was employed to remove $\mathrm{Mn}$ from the solution. Chlorine dioxide of $8 \%$ concentration was added to the NCM solution at the equivalent ratios of $\mathrm{Mn}$ and the leaching rate for the metals left in the NCM solution was calculate by varying $\mathrm{pH}$. The results were listed in Table 2 . The $\mathrm{pH}$ level was varied from 2 to 4 and 6 for the test but the Co and Ni leaching rate did not change much since more than $95 \%$ was extracted unlike 
potassium permanganate. However, in case of Mn, the removal efficiency was improved from $39.2 \%$ to $58.2 \%$ and $60.5 \%$ as the $\mathrm{pH}$ level increased.

Co and Ni leaching rates did not change much with different chlorine dioxide volumes. However, Mn removal efficiency increased $72.9 \%$ when chlorine dioxide equivalent ratio for $\mathrm{Mn}$ was 1.5 times higher at $\mathrm{pH}=2$ and $87.1 \%$ when it was 2.0 times higher. Besides, the $\mathrm{Mn} / \mathrm{Ni}$ ratio fell to $17.9,9.8$ and 4.7 as the equivalent ratio increased from 2 to 3 and to 4 . When $\mathrm{pH}$ was 6 with 1.5 times equivalent ratio, it went up to $77.4 \%$ and the $\mathrm{Mn} / \mathrm{Ni}$ ratio was 7.9, up 50\% compared with one time equivalent ratio. To sum up, as the $\mathrm{pH}$ and equivalent ratio increased, $\mathrm{Mn}$ removal efficiency also improved and the $\mathrm{Mn} / \mathrm{Ni}$ ratio that could separate Co and $\mathrm{Ni}$ easily with solvent extraction was less than $5 \%$.

TABLE 3

Results of Mn removal from NCM solution using $\mathrm{ClO}_{2}$

\begin{tabular}{|c|c|c|c|c|}
\hline \hline Conditions & $\begin{array}{c}\text { Co leaching } \\
\text { rate }\end{array}$ & $\begin{array}{c}\text { Ni leaching } \\
\text { rate }\end{array}$ & $\begin{array}{c}\text { Mn } \\
\text { leaching } \\
\text { rate }\end{array}$ & $\mathbf{M n} / \mathbf{N i}$ \\
\hline $\begin{array}{c}\mathrm{pH}=2.0 \\
\mathrm{ClO}_{2} / \mathrm{Mn}=2\end{array}$ & $99 \%$ & $99 \%$ & $60.8 \%$ & 17.9 \\
\hline $\begin{array}{c}\mathrm{pH}=4.0 \\
\mathrm{ClO}_{2} / \mathrm{Mn}=2\end{array}$ & $94 \%$ & $99 \%$ & $41.8 \%$ & 16.0 \\
\hline $\begin{array}{c}\mathrm{pH}=6.2 \\
\mathrm{ClO}_{2} / \mathrm{Mn}=2\end{array}$ & $95 \%$ & $98 \%$ & $39.5 \%$ & 15.8 \\
\hline $\begin{array}{c}\mathrm{pH}=2.0 \\
\mathrm{ClO}_{2} / \mathrm{Mn}=3\end{array}$ & $96 \%$ & $99 \%$ & $22 \%$ & 9.8 \\
\hline $\begin{array}{c}\mathrm{pH}=2.0 \\
\mathrm{ClO}_{2} / \mathrm{Mn}=4\end{array}$ & $95 \%$ & $99 \%$ & $12 \%$ & 4.7 \\
\hline $\begin{array}{c}\mathrm{pH}=6.2 \\
\mathrm{ClO}_{2} / \mathrm{Mn}=3\end{array}$ & $98 \%$ & $99 \%$ & $23 \%$ & 7.9 \\
\hline
\end{tabular}

In this study, the solvent extraction test was carried out to get rid of $\mathrm{Mn}$ by using solution with the $\mathrm{Mn} / \mathrm{Ni}$ ratio lower than 0.05 (1,700 ppm of Mn concentration). The solvent here was D2EHPA with $\mathrm{O} / \mathrm{A}=1$ and initial $\mathrm{pH}$ at 2.0. First of all, the various tests were performed depending on different concentration of extraction agent in the extraction process. The extraction agent concentration changed from 10 vol\% to 40 vol\% with $10 \%$ interval and the results were shown at Fig. 1.

Extraction ratio of Mn increased from $19 \%$ to $50 \%$ as the extraction agent of D2EHPA concentration increased to $40 \mathrm{vol} \%$. Extraction ratios of $\mathrm{Co}$ and $\mathrm{Ni}$ was decreased until the extraction agent concentration reached at $30 \mathrm{vol} \%$, however, they slightly increased from $30 \mathrm{vol} \%$. As $\mathrm{Co}$ and $\mathrm{Ni}$ leaching rate was the lowest at about $6 \%$ and $8 \%$ at $30 \mathrm{vol} \%$, the test after this fixed the concentration at $30 \mathrm{vol} \%$. After this, the study continued the test by changing the phase ratio (ratio of organic and water volume) in the extraction process and the result was shown at Fig. 2.

The Mn extraction rate rose as the phase ratio grew and it was about $72 \%$ at $\mathrm{O} / \mathrm{A}=2$. Co and $\mathrm{Ni}$ leaching rate also increased as the phase ratio went up and they were about $10 \%$ at $\mathrm{O} / \mathrm{A}=1$ or more. However, Mn removal requires multiple extraction stages as one solvent extraction made about 50\%. Fig. 3 illustrated the

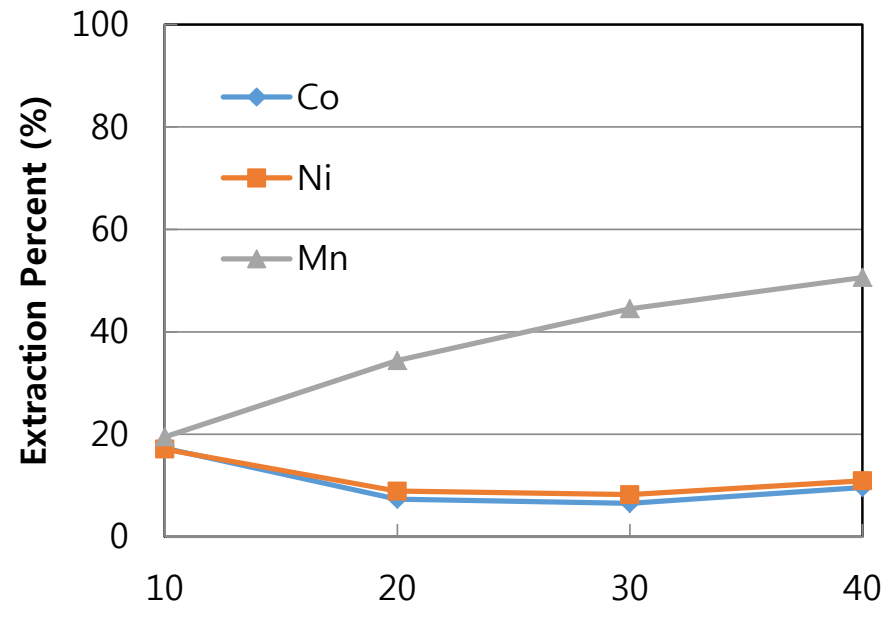

Amounts of D2EHPA (\%)

Fig. 1. Changes in extraction of $\mathrm{Co}, \mathrm{Ni}$ and $\mathrm{Mn}$ with varying the amount of D2EHPA

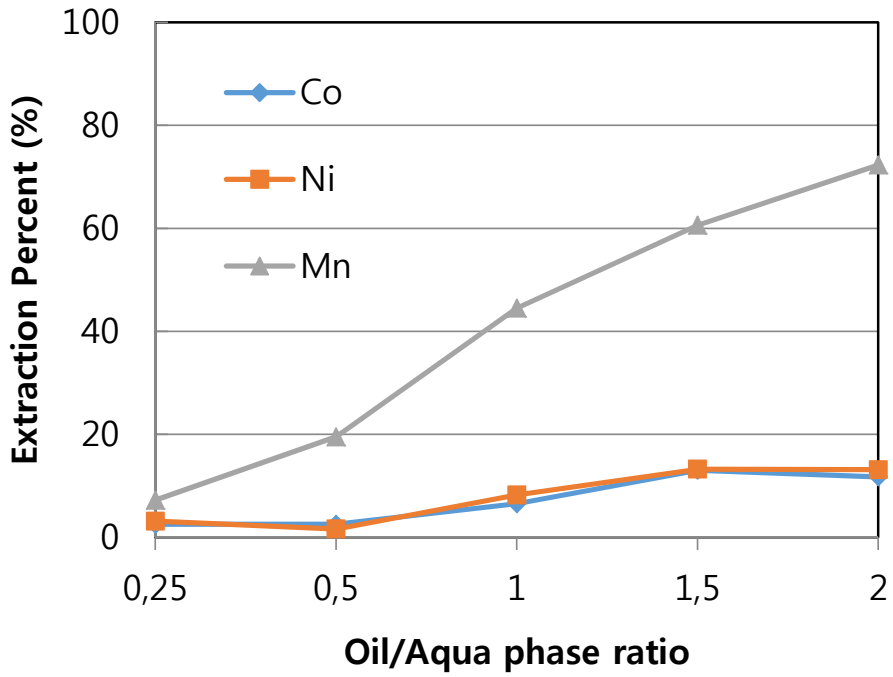

Fig. 2. Changes in extraction of $\mathrm{Co}, \mathrm{Ni}$ and $\mathrm{Mn}$ with the ratio of organic and water volume

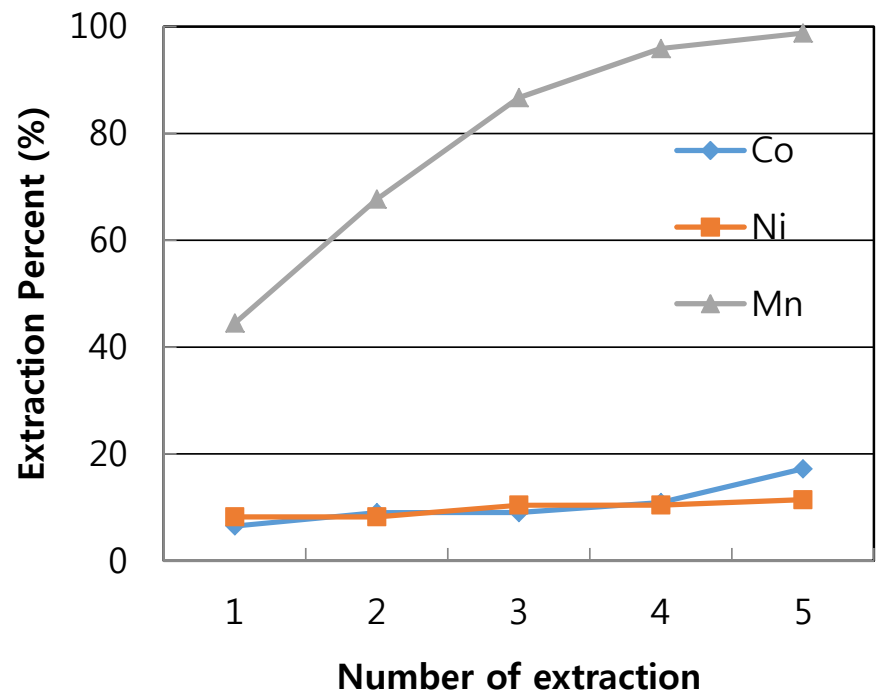

Fig. 3. Changes in extraction of $\mathrm{Co}, \mathrm{Ni}$ and $\mathrm{Mn}$ with the number of extraction experiments 
extraction rate result depending on the number of extraction and Mn recorded about 99\% leaching rate after five solvent extractions while Co and Ni did 17\% and 11\%, respectively.

In this study, the solvent extraction was conducted to separate $\mathrm{Co}$ and $\mathrm{Ni}$ from the leaching solution without Mn using the extraction agent D2EHPA under the condition of 15\%-Cyanex272 with O/A of 2 and initial $\mathrm{pH}$ of 5.5. The Co leaching rate was higher than $99 \%$ at $\mathrm{pH}=5.0$ and $\mathrm{Ni}$ was extracted by less than $7 \%$ rendering that $\mathrm{Ni}$ and $\mathrm{Co}$ were efficiently separated.

\section{Conclusion}

The study reached the following conclusion on the extraction behavior through solvent extraction to separate and recover Co, Ni and Mn by using NCM system sulfuric acid solution.

1) As for the NCM sulfuric acid solution with the Mn-to-Ni ratio at around 0.4 , the separation coefficient was found less than 10 when PC88A and Cyanex272 were used, and Co and $\mathrm{Ni}$ were not effectively separated. Both extraction agents were found inefficient in separating $\mathrm{Co}$ and $\mathrm{Ni}$ when there was lots of Mn since Ni should be separated in a solution but was extracted $45 \%$ and more on organic phase.

2) Oxidants such as potassium permanganate $\left(\mathrm{KMnO}_{4}\right)$ and chlorine dioxide $\left(\mathrm{ClO}_{2}\right)$, were used to remove $\mathrm{Mn}$ from NCM sulfuric acid solution. It was identified that chlorine dioxide had the better removal ability. Chlorine dioxide, when reacted twice as $\mathrm{Mn}$, showed $\mathrm{Mn}$ leaching rate at about $12 \%$ and $\mathrm{Co}$ and $\mathrm{Ni}$ leaching rates at around $95 \%$ and 99\%. This minimized loss of Co and Ni and successfully removed $\mathrm{Mn}$.

3) When Mn was removed by the oxidant to perform the solvent extraction test with $\mathrm{Mn} / \mathrm{Ni}=5.3$, using 20\% PC88A offered Co and Mn leaching rates at about 96\% and 99\% as well as Ni leaching rate at around 4 3\%. Using 15\% Cyanex272 suggested both Co and Mn leaching rate $99 \%$ and more as well as Ni leaching rate at around $4 \%$. Co and $\mathrm{Mn}$ separation coefficient for $\mathrm{Ni}$ was 10,000 or more, meaning one extraction was enough to separate $\mathrm{Co}$ and $\mathrm{Ni}$ in general.

4) Solution whose $\mathrm{Mn} / \mathrm{Ni}$ ratio was $5 \%$ and lower (Mn concentration at around 1,700 ppm) was used to carry out the solvent extraction test to remove Mn first. The test using 30vol.\% D2EHPA of O/A = 1 and the initial $\mathrm{pH} 2.0$ exhibited $\mathrm{Mn}$ leaching rate at about $45 \%$ and $\mathrm{Co}$ and $\mathrm{Ni}$ leaching rates at about $6 \%$ and $8 \%$ respectively. Beside five courses of solvent extraction suggested Mn leaching rate at $99 \%$ and more with $\mathrm{Co}$ and $\mathrm{Ni}$ leaching rate near $17 \%$ and $11 \%$. The test using 15\% Cyanex 272 of $\mathrm{O} / \mathrm{A}=2$ and the initial $\mathrm{pH} 5.5$ for the Mn-free solution by the leaching agent D2EHPA presented that the Co leaching rate was $99 \%$ and more at $\mathrm{pH}=5.0$ while $\mathrm{Ni}$ was extracted less than $7 \%$, separating $\mathrm{Ni}$ and Co efficiently.

\section{REFERENCES}

[1] H.C. Jung, G-H. Kim, H.S. Hong, D-W. Kim, J. Korean Powder Metallurgy Institute 17, 175 (2010).

[2] H.K. Park, J. Korean Electrochem. Soc. 11, 197 (2008).

[3] H.S. Hong, Y-D. Ko, L-S. Kang, H-C. Jung, G-H. Kim., J. Korean Powder Metallurgy Institute 18, 196 (2011).

[4] G.C. Shim, Trend in Metals \& Materials Engineering 24, 49 (2011).

[5] P. Zhang, T. Yokoyama, O. Itabashi, T.M. Suzuki, K. Inoue., Hydrometallurgy 47, 259 (1998).

[6] M. Contestabile, S. Panero, B. Scrosati, J. of Power Sources 92, 65 (2001).

[7] C.K. Lee, N.H. Kim, J. Korean Inst. of Resources Recycling 10, 9 (2001).

[8] S. Castillo, F. Ansart, C. Laberty-Robert, J. Portal, J. of Power Sources 112, 247 (2002).

[9] J. Nan, D. Han, X. Zuo, J. of Power Sources 152, 278 (2005).

[10] R. Wang, Y-C. Lin, S-H. Wu, Hydrometallurgy 99, 194 (2009).

[11] C. Liang, T. Xin-cun, Z. Yang, Q.U. Yi, W. Zhi-min., The Chinese J. of Nonferrous Metals 21, 1192 (2011).

[12] S.K. Kim, The 2011 spring meeting and $36^{\text {th }}$ conference, Korean Inst. of Resources Recycling, 84 (2011).

[13] D.W. Kim, S.T. Jang, K.M. Baek, J. Korean Inst. of Resources Recycling 22, 43 (2013).

[14] D.W. Kim, S.T. Jang, J. Korean Inst. of Resources Recycling 22, 62 (2013). 